Article

\title{
Online Sales and Business Model Innovation in Art Markets: A Case Study
}

\author{
Alexandra Fernandes ${ }^{1, *}$ and Luís U. Afonso ${ }^{2}$ \\ 1 Instituto Universitário de Lisboa (ISCTE-IUL), Business Research Unit (BRU-IUL), Avenida das Forças \\ Armadas, 1649-026 Lisboa, Portugal \\ 2 Faculdade de Letras da Universidade de Lisboa, Alameda da Universidade, 1600-214 Lisboa, Portugal; \\ luis.afonso@letras.ulisboa.pt \\ * Correspondence: alexandra.fernandes@iscte-iul.pt
}

Received: 24 December 2019; Accepted: 19 January 2020; Published: 21 January 2020

\begin{abstract}
Every year online sales represent a higher percentage of the sales total in nearly all sectors of the economy, and the art markets are no exception. However, there are few empirical studies showing how online sales and digital technologies are transforming the art markets at a micro-level. This study is based on the detailed examination of the financial performance of one of the two largest Portuguese auction houses, Cabral Moncada Leilões (CML), over a period of twelve years (2007-2018), complemented with interviews with its top-managers. It analyses a set of financial indicators (e.g., EBIT, ROA, EQUITY, sales volume, net results, etc.), along with some markers that are specific to the auction sector (e.g., average lot value, number of auctions per year, etc.). From this analysis it is possible to conclude that the deterioration of this company's financial performance was the driving force that led it to explore the potential of digital economy. In the process, its business model changed dramatically, leading the company to a different market position and to the enlargement of its national and international customer base.
\end{abstract}

Keywords: online sales; online auctions; art markets; digital economy; financial performance; business model

\section{Introduction}

The idea of selling art and antiques online was born in the late 1990s, when the usage of the internet was growing exponentially among common users. However, most of the websites created by then did not survive the collapse of the "dot.com bubble" in the year 2000 (Moulin 2003, pp. 102-3; Horowitz 2011, p. 212; Adam 2014, p. 121). Despite this temporary setback, information and communication technologies (ICT) deeply transformed the way we buy, think and interact with each other, including in the art markets. As consumers we have now multiple online channels to choose from, including social media, search engines or price comparison sites (Johansson and Kask 2017). We are getting more and more dependent on E-commerce (electronic-commerce), namely by the development of M-commerce (mobile commerce), that is, all kind of monetary transactions conducted over wireless telecommunication networks, and by the expansion of U-commerce (ubiquitous commerce), that is, the dynamic convergence of traditional commerce with digital technologies supporting permanent and personalized exchange of information between customers, retailers and cloud computing systems (Wu and Hisa 2004). Ultimately, these new cyber-physical technologies intend to improve the communication between systems using artificial intelligence methods of auto-optimization, self-diagnosis and self-configuring, in the spirit of the so-called Industry 4.0 (Vrchota et al. 2019). However, at least until now, all this digital technology is being used mainly to promote global art-world brand names and a celebrity culture in the arts, creating the illusion that the art markets are democratic and that the masses are part of it (Zarobell 2017, pp. 212-15; Milano 2019). 
The scale, nature and comprehensiveness of the changes taking place explain the exceptional growth of the online business industry, which is clearly outpacing the growth of the traditional retail industry, namely in fast growing economies such as India and China (Victor et al. 2018). In spite of the art markets' customary reluctance to change, its anti-technological leanings and its reserve concerning the provision of information, the development of ICT provided greater access and transparency about prices, supply and demand (Horowitz 2011, p. 212; Zorloni 2013, p. 4; Robertson 2016, pp. 215-17). These transformations opened the way for many entrepreneurs with innovative solutions who created value by developing inventive online business models directly linking producers and consumers, or consumers to consumers (C2C), and by finding business solutions that could operate on a global scale, bypassing many traditional intermediaries and gatekeepers, both in the primary market (first sale of a work of art) and in the secondary market (subsequent sales) (Samdanis 2016). Cryptocurrency, blockchain and artificial intelligence are the most relevant innovations that are currently shaping the immediate future of the online art market and, most likely, the future of the art market as a whole (Sidorova 2019).

According to (McAndrew 2019, p. 260), in 2018 online sales in the art markets have reached nearly USD 6 billion, representing 9\% of the turnover of this sector, doubling the USD 3 billion achieved in 2013. However, not only is this percentage slightly behind the online sales' percentage of the retail sector in general, where it represents $12 \%$ of the total, but it is also growing at a slower rate than the online sales of that sector, $9.8 \%$ against $18 \%$ (Hiscox 2019, p. 2). This divergence can be explained by the specificity of the art markets. First, a large percentage of the art markets' value originates from the top-segment, which involves the trading of highly valuable and unique items, or nearly unique, each one with its singularity and with a low degree of substitutability, features that do not benefit agents competing on the basis of price (McAndrew 2010, pp. 17-19; Samdanis 2016). Second, the most relevant customers belong to an older generation (Silent Generation, Baby Boomers) who are more resistant to online buying, in contrast to younger generation (Generation X) and especially with the youngest generation (Millennials, Generation Z). The latter use mobile devices and social media more intensively for sourcing and purchasing art, dismissing the need of experiencing the work of art in person before buying it, particularly in the case of less expensive works (Hiscox 2019, p. 12; McAndrew 2019, pp. 264-67; Sidorova 2019). Third, some major concerns in the art markets are related to issues of authenticity, provenance and conservation status, which are particularly problematic in the case of non-specialized internet platforms such as eBay and the like (McNulty 2014, p. 37; Sidorova 2019). Finally, direct social interaction is still very relevant in the art markets, namely when it overlaps with the sense of belonging to the art world community and/or to the jet-set community, as a luxury experience involving prestigious and glamorous brands. Indeed, in the top segment of the art market, personal interaction is essential to nurture relationships and to make new reliable contacts (Velthuis 2005, pp. 44-47; Moureau and Sagot-Duvauroux 2012, pp. 77-78). Thus, very expensive works of art (as well as large or fragile works) are more difficult to trade online (Robertson 2016, pp. 215-17; Adam 2017, pp. 191-92; McAndrew 2019, pp. 304-5).

For all these reasons, it is not surprising to find that the large majority of online sales in art markets are made in the lower and mid-price segments, particularly in the case of online-only companies (Moulin 2003, p. 102; Samdanis 2016; Pownall 2017, p. 35; McAndrew 2019, p. 264). Two sectors that profited most from the internet were contemporary photography as an art form, which benefits from the ease of display in online environments and the universal familiarity with photographic images (Boloten 2016, p. 73), and also the so called "collectible objects", namely ceramics, prints, rare books, memorabilia and silverwork, which are now easily found by collectors in major aggregator sites, displaying instantaneously the merchandise available for sale on thousands of different vendors from all over the world and allowing to compare prices immediately (McNulty 2014, p. 37). Furthermore, as we will see with the Portuguese auctioneer Cabral Moncada Leilões (herein after referred to as CML), by furthering disintermediation the internet made art markets more accessible to those living outside the big cities, where there are no art galleries or relevant exhibition venues (Sheffield 2017). However, 
it is important to note that in addition to their sales role, online channels have become extremely important as the major source of new clients for art galleries and auction houses, particularly those operating in the lower and middle tiers (McAndrew 2019, pp. 272-75, 304).

Online auctions are the most relevant sector of online art markets by value (McAndrew 2019, p. 272). From 2005 to 2015, the number of auction houses with a presence on the internet jumped from 3\% to 95\%, with a particular emphasis on online access through mobile devices (Ehrmann 2016, pp. 6-7). Most of traditional brick-and-mortar auction houses have increased their offer in online-only auctions, using their own platforms or third-party platforms to sell those parts of large collections that do not entirely fit the standards of their traditional live auctions or that have lower estimate prices (McAndrew 2019, p. 272). As we will see in the next sections, this was precisely the strategy followed by CML, who mainly offers low and mid-price works of art in online-only auctions carried through its own platform, reserving the higher-price and higher-quality works for live auctions and online bidding through major international third-party platforms. In addition to these online-only auctions, the major worldwide players in this area, namely Christie's, Sotheby's, Phillips, Bonhams, Dorotheum and Heritage Auctions are also receiving a growing number of online biddings in their live auctions (Hiscox 2019, p. 3; McAndrew 2019, p. 273). These major players are introducing more sophisticated augmented/virtual reality applications and artificial intelligence technology in order to improve the interaction with their customers. The introduction of image recognition software to suggest similar works coming up for sale to those already bought or selected by the viewers is becoming a common procedure. Likewise, more companies are introducing innovative financial solutions, such as the acceptance of crypto-currencies and the possibility of group purchases through crowd-funding and the virtual segmentation of works of art into stocks (Sheffield 2017; Milano 2019; Sidorova 2019).

Besides the growing relevance of online sales for the major auction houses, third-party electronic platforms such as Invaluable, Saleroom, LiveAuctioneers, and Artsy are among the companies that are benefitting more from the growth of online sales in the art markets (Hiscox 2019, p. 7; McAndrew 2019, p. 275). Every year these platforms have more auction houses among their clients, sell more lots, have higher average prices and have a higher number of hosted auctions. At the same time, we are witnessing a consolidation process involving online purchasing platforms and associated services, such as blockchain providers and online sales databases. Three good examples of this process were: (a) the acquisition in 2017 and 2018 of CollectorsWeekly.com, Simple Auction Site and the valuation service ValueMyStuff by Barnebys.com, a well-known search engine of design, antiques and collectibles; (b) the merger in 2018 of Paddle8, a global online auction house based in New York, with The Native, an international technology media company specialized in data analytics, blockchain technologies and digital marketing; (c) the integration in 2018 of the German-based auction platform Lot-tissimo in the Auction Technology Group, holder of Saleroom (Hiscox 2019, p. 6; Milano 2019; Saleroom 2019). It is interesting to remember that this well-known online platform, Saleroom, emerged in 2006 from the widely read journal Antiques Trade Gazette, being now one of the group's most valuable assets. In this bustling environment, many new and innovative online services are emerging, such as Auctionaftersale.com, a site that during ten days assembles bids for unsold items at auction, aggregating more than 2500 companies, or such as thirdman.com, a site that provides a search-and-offer service for works of art previously specified covering a large spectrum of auction houses (McAndrew 2019, p. 284).

In sharp contrast with the auction sector, online sales still represent a small percentage of art gallery sales, namely those with higher turnovers. On average, online sales represent only $6 \%$ of art galleries' turnover, two thirds being made by their own web channels and 1/3 being made through third-party platforms such as Artsy (McAndrew 2019, p. 292). However, bigger galleries are investing heavily on analytical tools and technology, not so much to foster online sales, but mainly to provide their clients with engaging online experiences of the works of art prior to their visit to the galleries and art fairs boots. Online viewing rooms with high resolution images, complemented with information on prices and on the availability of the works of art are being used in conjunction with artificial intelligence, 
big data, virtual reality, and augmented reality technologies, in order to make these leading galleries also a reference in this area, enabling them to know better their clients and to offer them a top-quality digital service (McAndrew 2019, pp. 300-2; Sidorova 2019).

The transformations induced by ICT developments in the art markets are undeniable (Flynn 2016; Hackforth-Jones and Robertson 2016). However, few empirical studies have been conducted to analyze how these technologies are transforming the art markets at a micro-level, namely due to the growing relevance of online sales. The goal of this study is to analyze the impact of ICT and online sales over CML, one of the two largest Portuguese auction houses. This analysis covers a period of twelve years (2007-2018) and shows how CML's business model changed dramatically, leading the company to a different market position and to the enlargement of its customer base.

\section{Materials and Methods}

Art markets are mainly concentrated in three countries: USA, UK and China. Together, these countries represent $84 \%$ of the global art market's total value (McAndrew 2019, p. 16). In comparison, the Portuguese art market is almost insignificant, representing $0.15 \%$ of that value, while the Portuguese auctioneer CML is even smaller, representing only 0.01\% (Afonso 2012, p. 29; Afonso and Fernandes 2019, pp. 197-98). In spite of its modest scale on a global perspective, CML is one of the two leading auctioneers in Portugal and is a paradigmatic case-study. Indeed, the conclusions that can be draw from its financial performance and strategic management are highly interesting, revealing how the adoption of digital technologies has led to a profound modification of its business model. In the first part of this section we explain the research method employed to analyze the data collected. In the second part we present an overview of this company's history.

\subsection{Research Method: Interviews and Financial Statements}

The data to address our research questions was obtained from the analysis of interviews and financial statements. Between June 2018 and October 2019, we conducted six semi-structured qualitative face-to-face interviews with the two CEOs of CML, with an average duration of 90 minutes each. ${ }^{1}$ These two persons are simultaneously the owners and responsible for the strategic management of the company. They were responsible for the decision to invest significantly in ICT in 2016. Therefore, they are the ones who could better describe and explain ICT's impact on their company's business model and performance.

According to Patton (2002, p. 244), in qualitative studies, there are no specific numbers for an ideal sample size, and the number of interviews we conducted were enough to obtain the data we needed. All the interviews were recorded and transcribed by the authors. After, the interviews were sent to the CEOs to ensure the credibility of the study findings. The data was analyzed by content analysis and the data saturation was achieved (Morse 2015). The interviews were complemented with an analysis of CML's balance sheets and profit and loss statements, covering the period from 2007 to 2018. In particular we examined the turnover of the company, the number of auctions conducted (both online-only and live), the number of lots sold and their average price (both online-only and live), the number of employees and, most importantly, the company's net results. Our analysis was also focused on several financial indicators, not all of them included in this paper, namely the company's current ratio, the debt ratio, the debt to equity ratio, and the return on assets (ROA) ratio.

Throughout this paper we mention some historical prices, namely the former Portuguese currency escudos and its multiple unity contos (one thousand escudos). In order to update these prices and make them more comprehensible, we used the historical currency converter provided by the portal Pordata. ${ }^{2}$

1 These six interviews were conducted with the two CEOs of CML. One was interviewed four times (INT02, INT04, INT05, INT06), and the other two times (INT01, INT03).

2 Pordata. https://www.pordata.pt/Portugal, accessed on 7 November, 2019. 


\subsection{A Second Tier Auction House: Cabral Moncada Leilóes (CML)}

CML is one of the two dominant auction houses operating in Portugal (Magalhães 2008, pp. 259-60; Fernandes and Afonso 2012, p. 5; Teixeira 2012; Afonso and Fernandes 2019, pp. 362-70). From an international point of view, it can be classified as a second tier auction house operating on a national basis. This auction house was established in Lisbon in 1996 by three partners: António Trincão, who had the premises and most of the capital; and the Cabral Moncada brothers, Francisco and Miguel, who had the know-how. In June 1984 these two brothers opened a small antique shop in a traditional neighborhood in Lisbon. At that time, they were only 26 and 21 years old, respectively, but they already had a deep familiarity with the antiques trade. Their father was an acknowledged antique dealer, who was established in Lisbon since 1962 with the antiquary Cabral Moncada Antiguidades. In addition, their great-uncle, Jacinto Temúdo, was also an antique dealer, and played a decisive role on their father's decision to start is business as an antique dealer: "He was probably the most important dealer in Lisbon between the 1920s and the 1950s. His antiquary ( . . ) took his name Jacinto Temúdo" (INT02).

The entrepreneurial kick-off for Francisco and Miguel was the sale of several items that their father kept at home: "The old maid's room was full of stuff that my father kept buying. Objects that were not yet restored or that were not in condition to be taken immediately to his antiquary. My mother, of course, was always claiming that room, time after time. Until one day my father made us a proposal: "you make the inventory of that, negotiate it with an auctioneer of your choice, and $50 \%$ of the sale is yours»" (INT02). The sale was held at the auction house Soares \& Mendonça, in 1983, and they received 174 contos, that is, circa EUR 5.300 in today's values. Soon after, they opened their shop in Lisbon: "It was with the sale of that stuff, nearly 150 pieces of small and medium sizes, that we got the money to establish our own business. We travelled together with our father, we conducted some business together, but from the start that we were totally independent from him" (INT02). Two years later they opened a second shop in Estoril, a fashionable location west of Lisbon, and in 1987 they start to travel abroad for business and moved from their small shop at Bairro Alto to a larger one at Rua de São Bento, where most of the antiquaries were established in the nineteen eighties (Magalhães 2008, p. 260; Afonso and Fernandes 2019, p. 339). In 1989, Miguel lived the whole year in London, buying antiques at auction and sending those items to Portugal, in order to be sold at their two shops. The 1980s were a highly expansive market period for antiques in Portugal, fueled by an annual GDP growth of between $4 \%$ and 7.5\% (Afonso and Fernandes 2019, pp. 199-201). Miguel Cabral Moncada recalls that in that year their turnover reached nearly 90.000 contos, that is, almost EUR 1.1 million at today's values, jumping from circa 33.000 contos in the previous year.

However, due to their knowledge of the art markets in London and Paris, and due to the evolution of the antiques market in Portugal, the two brothers realized that the future of their business lay in the auction sector. They were sure that one day they would become auctioneers: "In 1990, at a lunch with João Pinto Ribeiro, CEO of the newly founded auctioneer «Palácio do Correio Velho», he invited us to be undertaker agents of his. We told him that we appreciated his offer, but it was our intention to establish our own auction house in the future" (INT02). The economic crisis of the early 1990s reinforced their perception and in the summer of 1995, they finally decided to open their auction house, choosing António Trincão as their partner. However, Francisco kept running the antiquary and it was Miguel who assumed the responsibility of launching and managing the new company. Not surprisingly, they decided to name their auction house as Cabral Moncada Auctions, boosting the recognition of a brand already well-known in the Portuguese trade. They opened the company in January 1996 and in February they made their first auction. In 1999 a new partner entered into the society, Pedro Alvim, and in 2004 António Trincão decided to sell his share in the company. At that time, CML was growing in terms of turnover and prestige, moving closer to the position of the Portuguese auction market leader, Palácio do Correio Velho: "Our business continued to expand until 2006, year after year. However, in 2007 we lost money for the first time, around EUR 45.000, without knowing why" (INT05). In spite of this setback, from 2005 on, these two companies have shared the leadership 
of the Portuguese auction market in terms of turnover, each one selling between 5 to 8 million euros per year (Afonso 2012, p. 11).

In 2011, CML started to translate its "Special Auctions" catalogues (Leilões Especiais) into English, conducting two or three of these every year, remodeling also CML's webpage, involving ca. 45.000 pages. In 2015 CML joined the online auction platforms, Saleroom and Lot-tissimo, two of the leading portals for fine art and antiques auctions in Europe at that time, one based in the United Kingdom and the other based in Germany. ${ }^{3}$ One and a half years later, in October 2016, CML launched its own platform of online auctions, which represented a major shift on CML's business. The new online technologies provide the impetus for this transformation, leading to a reconfiguration of CML's organizational structure and market positioning. Two factors determined these changes. On the one hand, the company was pushed to work with lower average prices. The ever-growing prices on the top-segment of the market hide a different reality, namely the diminishing purchasing power of the high middle-class: "From 2007-2008 on the average prices of lots in the mid and lower segments have gradually decreased all over the world" (INT06). On the other hand, the disintermediation process has reduced the number of dealers buying and selling at auction, bringing more final consumers to the auction houses: "The business has madly changed. There are less and less dealers in the antiques sector. The costs of having an open shop, with one or two employees, the rising taxes, and so on, all that has become so expensive that it no longer pays. Therefore most of the antique shops have closed down. Some have offices at home, attend art fairs and sell and buy at auction. But they are less and less" (INT05).

If the business model, strictly speaking remains the same, that is, a business based on auctions, the truth is that the degree of change was so substantial that it implied a reinvention of the company as we will see later. However, with 22 full-time employees and nearly the same number of part-time collaborators, consultants and trainees, CML continues to be a typical family business, not only due to the number of the Moncada and Alvim family members working there (respectively, four and three, reaching nearly one quarter of the total), but also due to the kinship bonds between the employees (cousins, husband and wife, son-in-law, brother-in-law and sister-in-law, etc.): “This type of family structure makes everything easier, people get along better and it is also easier to integrate new people" (INT02).

\section{Results}

The analysis of CML's balance sheets and profit and loss statements reveals that its financial performance varied significantly over the last twelve years, both in terms of turnover as in terms of net results (Figure 1). In absolute terms, the two highest turnovers were achieved in 2011 (EUR 7.48 million) and in 2014 (EUR 7.38 million), while the lowest ones occurred in 2017 (EUR 5.13 million) and in 2008 (EUR 5.19 million). In terms of net results the best outcomes were achieved in 2011 (EUR 364,000) and 2012 (EUR 195,000), precisely when Portuguese GDP was experiencing one of its poorest performances since the reestablishment of democracy, in 1974, while the worst results of CML occurred in 2016 (EUR -171,000) and 2008 (EUR -87,000) (Figure 2). ${ }^{4}$ The loss of 2016 is striking, because in that year Portuguese GDP grew 2\%, its best result since 2010. This situation is interesting because it highlights a discrepancy in performances, showing a curious desynchronization between the art auction business and the economic performance of the country as a whole.

Indeed, it is highly significant that the best years of CML in terms of turnover and profitability almost coincided with the Portuguese bailout program for stabilizing its public finances, which became mandatory when the country was unable to refinance its government debt in the financial markets.

3 Currently, CML is associated with four online platforms: www.invaluable.com; www.the-saleroom.com; www.lotissimo.com; and www.bidspirit.com.

4 Pordata. https://www.pordata.pt/Portugal/Taxa+de+crescimento+real+do+PIB-2298, accessed on the 23rd of December 2019. 
Implemented between June 2011 and May 2014, this bailout implied a huge loan of EUR 78 billion from the International Monetary Fund (IMF), the European Financial Stabilization Mechanism (EFSM), and the European Financial Stability Facility (EFSF) (Portugal 2019, pp. 109-12). This was one of the most difficult periods of Portuguese economy since the early eighties. During this critical period, which spanned from 2010 to 2014, Portugal faced an intense austerity policy that severely affected art galleries in the primary market, antiquaries in the secondary market and the smaller auction houses. All these agents faced critical conditions in terms of economic and financial survival, with a large number of closures and bankruptcies (De Tomasi 2013; Nabais 2015, pp. 60-65; Simões 2015, pp. 297-302; Ramires 2018, pp. 76-78). However, the two major Portuguese auction houses, CML and Palácio do Correio Velho, were not affected by this extreme crisis and even prospered in this critical environment.

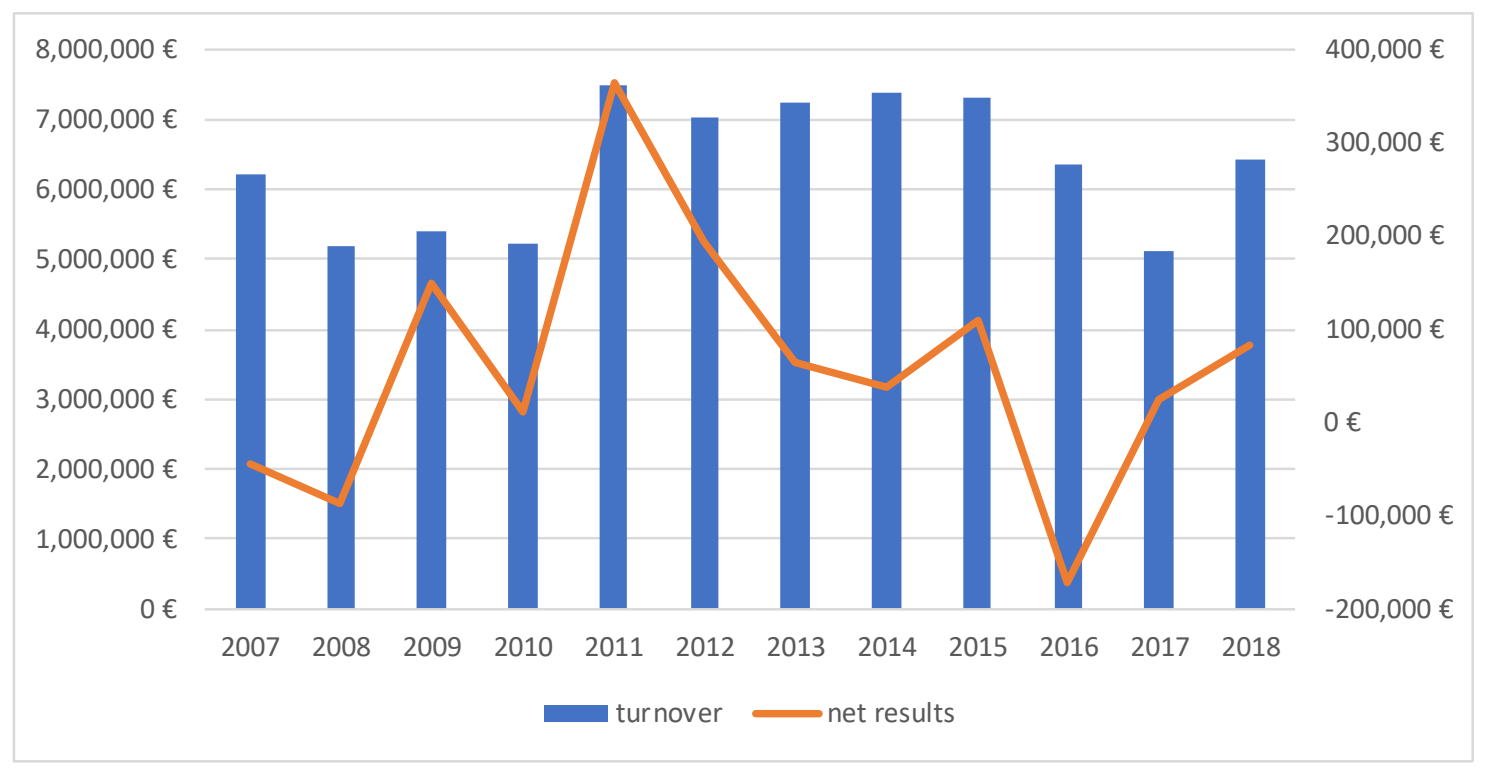

Figure 1. Cabral Moncada Leilões' (CML) turnover and net results (2007-2018).

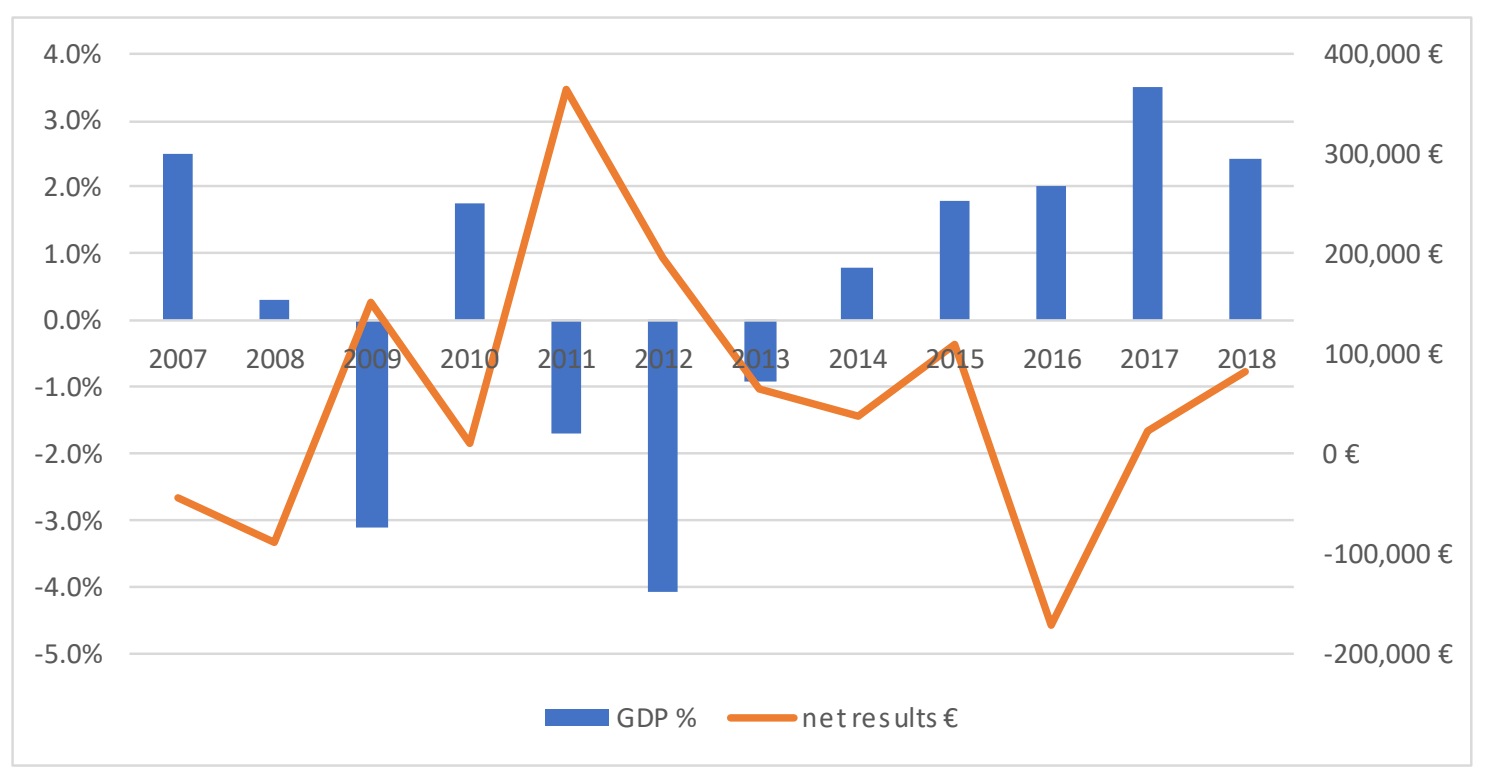

Figure 2. Portuguese GDP growth and CML's net results (2007-2018).

Part of the success of the major Portuguese auction houses during the bailout program is explained by the liquidity needs of many collectors and holders of works of art, who were forced to sell some of their most cherished belongings. It is worth remembering the critical situation deployed by the 
Global Financial Crisis (GFC) of 2007-2008 in Portugal: (a) a huge financial crisis with government deficits always above 3\% between 2008 and 2015, with a peak of 11.2\% in 2010; (b) a severe economic recession with negative GDP of $-3.12 \%$ in $2009,-1.7 \%$ in $2011,-4 \%$ in 2012 , and nearly $-1 \%$ in 2013 ; (c) the collapse of the stock market, with a 51.2\% decrease in 2008, a 27.6\% decrease in 2011, and a $26.8 \%$ decrease in 2014; (d) the high unemployment rate, always above $12 \%$, between 2010 and 2015 , with a peak of $17.3 \%$ in 2012; (e) a severe drop in real estate prices, of nearly $30 \%$, between 2007 and 2013; (f) a sharp decrease in real estate transactions, with half of the units being sold in 2013 when compared with 2010; (g) and, finally, the meltdown of several Portuguese private banks, such as Banco Português de Negócios, in 2008, Banco Privado Português, in 2009, Banco Banif, in 2012, and particularly Banco Espírito Santo, in 2014, that caused huge financial losses for many affluent households. This overwhelming combination of negative events created the perfect storm that forced several Portuguese collectors and families to sell some of their most valuable tangible assets (Afonso and Fernandes 2019, pp. 206-11).

Therefore, between 2010 and 2014 the conditions of the Portuguese art market were highly favorable to buyers, with many holders selling important works of art to obtain cash. In many cases, these sales were made below their market value, specifically works of art with a market limited to Portuguese buyers (e.g., Portuguese contemporary art, Chinese export porcelain with Portuguese heraldry, Portuguese ancient furniture, Portuguese naturalism painting, etc.). At the same time, the majority of works of art with an international market, namely Chinese art, Portuguese ultramarine art or international contemporary painting, were disputed by buyers from abroad, namely from Asia and Europe. Curiously, when the economic situation improved in 2015, the performance of CML started to decline, especially after the election of a new government in October. On the one hand, there was less pressure to sell, due to the recovery of the economy. On the other hand, the new minority Socialist govern, supported by the Portuguese Communist Party and by the Left Bloc (Bloco de Esquerda, a kind of post-modern Trotskyism), caused fear and encouraged caution among Portuguese economic elites and among the European institutions. Therefore, for several months the major economic agents, as well as the major collectors, took a prudent approach to the art market: "The political instability is the worst scenario for the art markets. Moreover, in this case, the presence of communists and other left-wing parties supporting the new government scared a lot of people. The market got immobilized. People neither bought nor sold. They didn't sell because they thought it was a bad time to sell. They didn't buy because they were afraid about what could happen and preferred to keep their money available for any emergency" (INT03).

\section{Discussion}

CML's financial performance started to present troubling indications during the last quarter of 2015, with major drops on the auction sales conducted between October and December, traditionally the best season for the auction market in Portugal: "In July, August and September we prepare the great auctions of the last quarter: one of important antiques, another of modern and contemporary art, and another of common antiques. All the material that we gather during the summer is distributed between these three auctions" (INT01). Those problems became more visible in the following year, when CML had a turnover decrease of nearly 15\%. From 2011 to 2015, CML always had an annual turnover above EUR 7 million: "During that period we always had people delivering us goods worth EUR 10 or 10.5 million as low presale estimates. In 2016 we only got EUR 6.8 million. It is true that we almost reached that amount in the end of the year, but one million was made with two rare Chinese Qianlong aquariums whose price rose fivefold during the auction. That doesn't happen often" (INT05). Moreover, in spite of having kept a high turnover in the previous years, the margin of the auction house was being squeezed until in 2016 it finally became insufficient to cover the breakeven point (all the expenses and the financial indicators entered in the red zone) (Figure 3). 


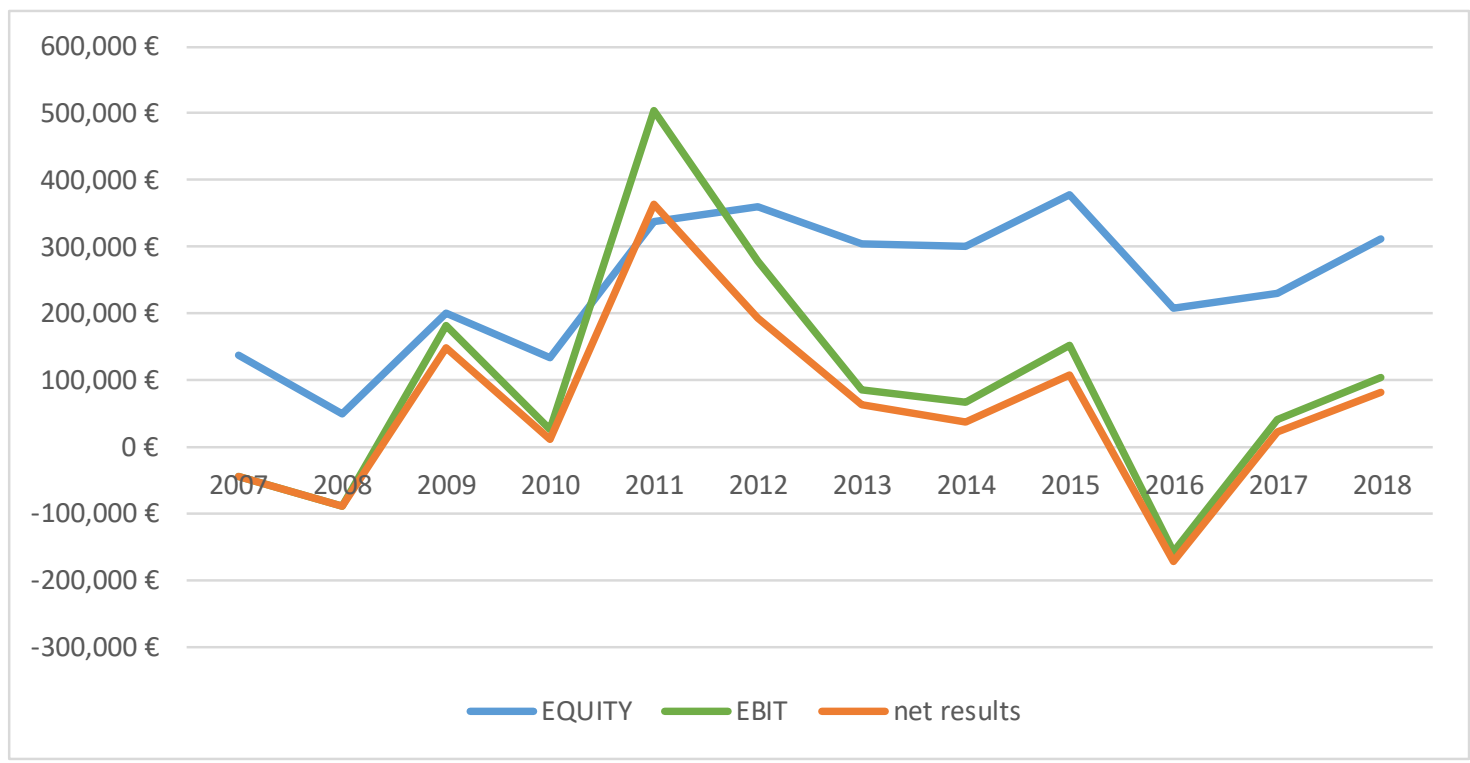

Figure 3. CML's main financial indicators (2007-2018).

The profit was getting smaller and smaller, decreasing from EUR 364.000 in 2011 to EUR 108.000 in 2015, with much lower values in 2013 and 2014. To keep the same volume in terms of turnover it was necessary to auction many more lots, implying a reduction in the average price of the works sold and an increase in the company's costs. Obviously, if more lots were being taken to auction and the turnover remained the same, it meant that there was either a higher number of unsold lots or that their average price was lower, or a combination of both possibilities. Irrespectively of the correct answer, if more lots were taken to auction it is easy to understand that CML's costs jumped in terms of consignments, inventory, transportation, catalogues, bulk mail, photography, storage and employees.

The analysis of the return on assets ratio (ROA), provides a clearer picture (Figure 4). This ratio shows how well a business uses its assets, determining how profitable a company is considering its total assets and debt. It is used mainly to compare with companies in the same area of business and with equivalent dimension, but it is also important to compare to its previous performance. In this case we can see that ROA varied between -15\% in 2008 and $17 \%$ in 2011. This ratio was negative only in 2007, 2008 and 2016, being positive in all the other years, with the highest results achieved in 2011, when it reached nearly $20 \%$.

Therefore, 2016 was not the first time CML had negative results. In 2007 and 2008 the company also had losses, but the value of those losses was much lower. At that time, the measures taken by the managers consisted on a $10 \%$ cut in the wages of the administration, a reduction of the size and weight of auction catalogues (EUR 10,000 savings per auction catalogue), a significant reduction of photographic costs and the suppression of certain social benefits, such as the daily offer of free breakfast to the employees (EUR 10,000 saving per year): "For the first time in my life I understood that I had to reduce the size of company. And I reduced the fixed costs by $17 \%$ without firing a single person" (INT04). In addition to these savings, CML started to charge transportation costs to sellers, who were now also obliged to pay a fixed fee of EUR 5 or EUR 10 per lot in order to have their items taken to auction, irrespective of whether they were sold or not. Finally, the commissions were also increased in what concerns sellers, while the commissions charged to buyers became more attractive. Most of these measures taken in the past, which produced positive results almost immediately, were now perceived as insufficient or inappropriate to current times forcing the introduction of major and innovative measures which, in the end, represented a change of CML's business model. 


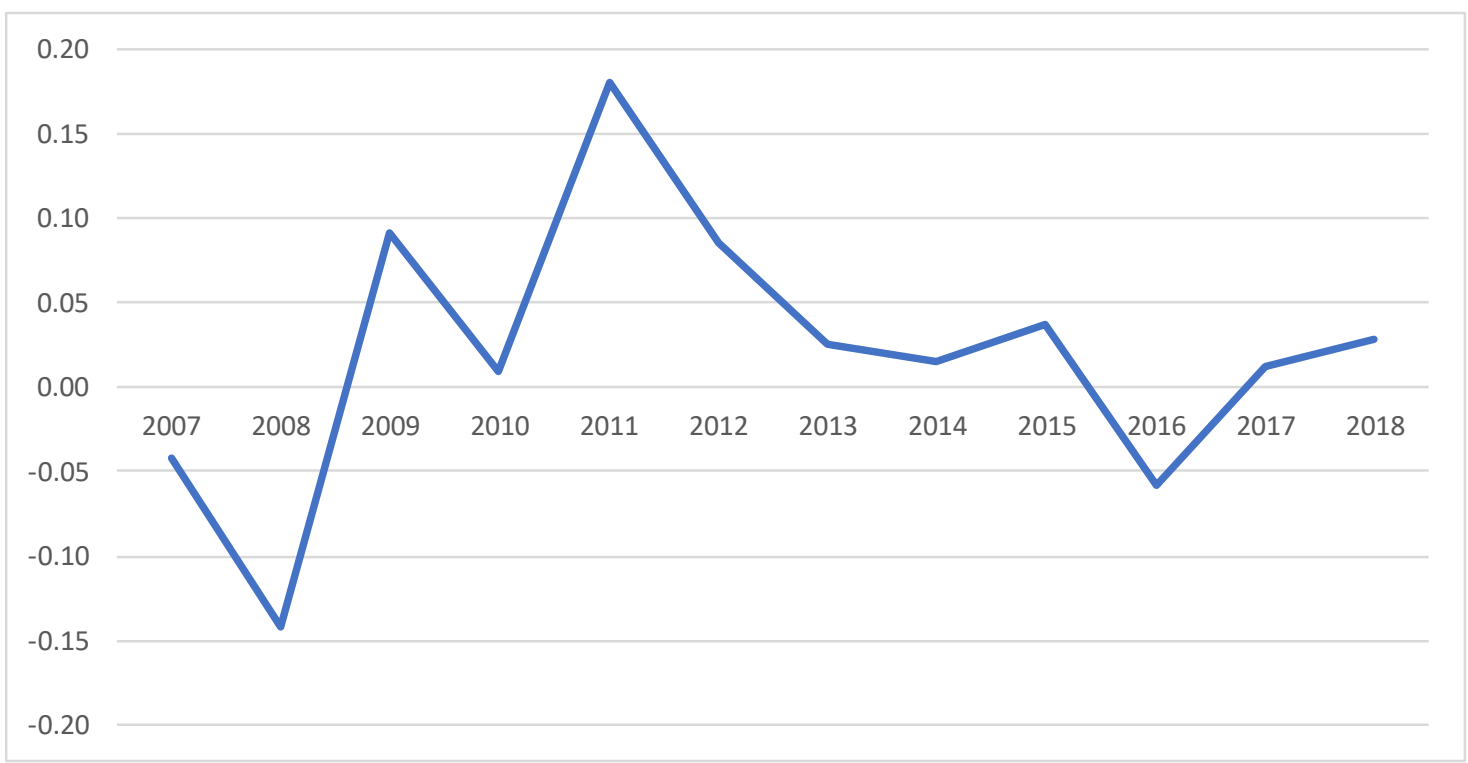

Figure 4. CML's return on assets ratio (ROA) (2007-2018).

In fact, the top managers realized that the traditional answer of costs reduction and the review of commissions would not be enough. At the same time, they were watching their main competitors developing their own online-only auctions: "Our main competitor, with whom we have a cordial relationship, kept saying «You need to go online. The business is changing dramatically. You need to go online». Indeed, they sensed the change sooner than us" (INT05). By then they already had established a partnership with Saleroom and Lot-tissimo and they were becoming aware that they also should do something by their own in the area. Thus, after an informal and unexpected proposal by a younger member of the family, who was not yet working in the company, they decided to give it a try: "Following a Christmas lunch in 2015, during all afternoon, we discussed with Luís da Costa Brandão, son-in-law of my sister, the possibility of starting our own online-auctions. Two weeks later he called us and showed us a comprehensive plan to implement this project and in that same day we decided to move on" (INT04). During the first half of 2016, CML kept developing its own platform for online auctions, investing heavily in software and hardware, allocating some employees to work only on this area. At the same time, however, the company was accumulating more losses with traditional live auctions. The new online platform was ended just before the summer 2016 and the first online only auction took place in October 2016. At the beginning, CML organized one online auction per week. By the end of 2016 nearly 15\% of total lots taken to auction consisted of online only lots (1809 from a total of 11,213), although the number of online auctions nearly matched the number of live auctions (nine online, 10 live). In that year, the turnover originating from the online only auctions was lower than EUR 100.000, representing 1.5\% of CML's global turnover (Figure 5).

However, in the following year, the transformation of the company and the change of its business model became clear. In spite of a huge reduction of the global turnover of CML to EUR 5.1 million, a $20 \%$ reduction in relation to the previous year, and in spite of having more employees, the company presented positive results at the end of that year, slightly above EUR 20,000. From 11 or 10 live auctions per year carried between 2009 and 2016, in 2017 CML reduced its offer to only seven live auctions while the online only auctions increased to 59. Likewise, the total number of lots taken to auction jumped to 18.418 , but nearly $72 \%$ (13.206) consisted of lots taken to online-only auctions. In 2017, online-only auctions represented 19\% of CML's turnover. In 2018, CML's turnover increased more than $25 \%$, to EUR 6.4 million, and the profit also increased four times, with online-only auctions 
representing 33.5\% of CML's turnover, a percentage that climbed to $43.5 \%$ in $2019 .{ }^{5}$ There was a further reduction of live auctions from seven to five, while the number of online-only auctions increased to 74. The total number of lots taken to auction at CML rose to 24.017 , but only 3.633 were placed on live auctions, that is, nearly one third of the numbers offered in 2014 and 2015 (Figure 6). In spite of a major reduction on the average price of each lot, the profitability of the company was not affected because the margins have increased due to a reduction of the discounts made to dealers and due to the higher commissions charged in the lowest segment of prices: "Nowadays around $95 \%-98 \%$ of our sales comes from private customers. No one makes commission discounts to private customers in the auction business. The relevance of dealers has decreased sharply. You need to understand that we kept the original commissions to those dealers who helped us to launch our company in the 1990s, when our commissions were lower. Most of these people are no longer on business. Some have died, some retired, and others closed their business. Besides, due to the progressive price range of our commissions system, buyers of low-price lots are now paying higher commissions" (INT05).

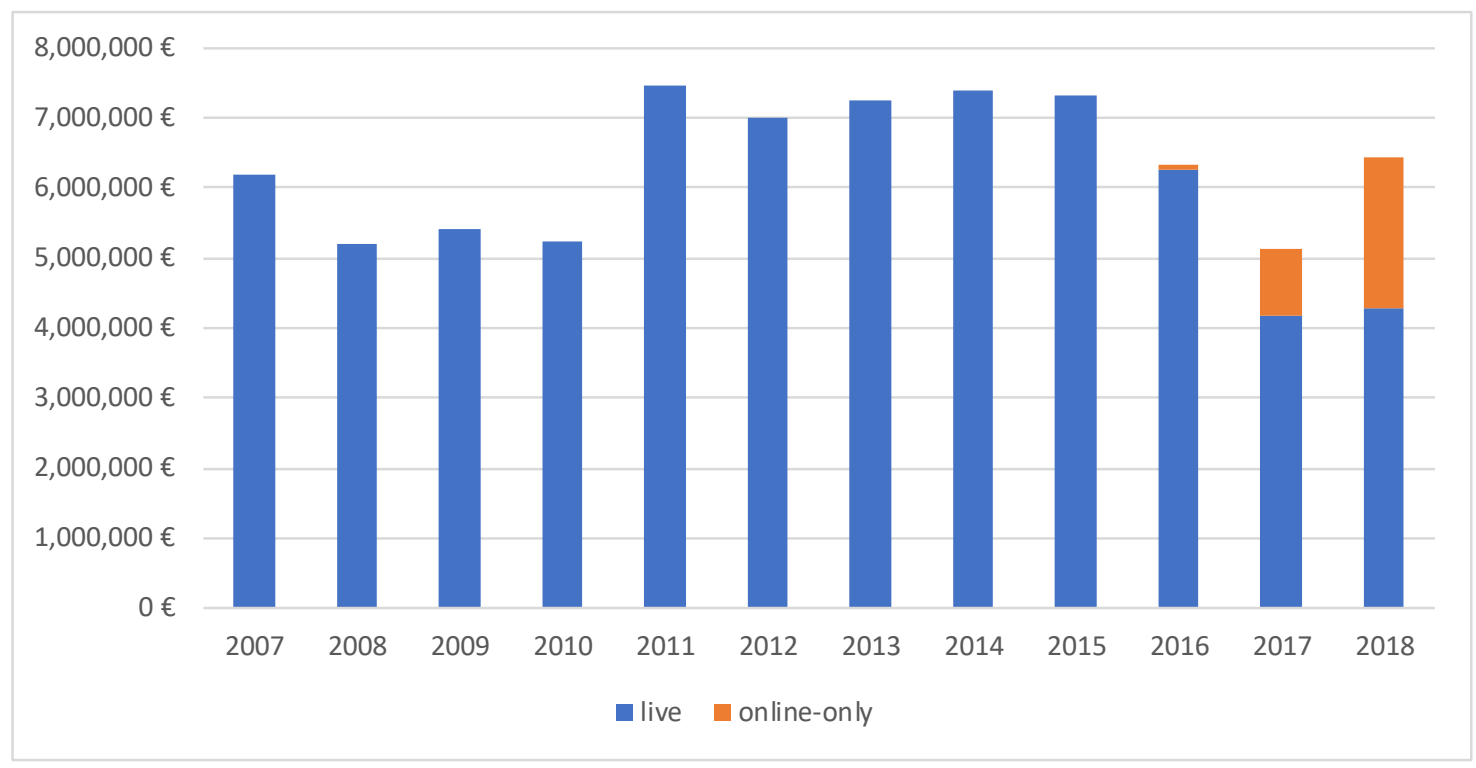

Figure 5. CML's turnover with the contribution of online-only auctions (2007-2018).

Furthermore, the national and international customer base of the company also increased significantly. The international customers are more frequent on live auctions, bidding through the two third-party platforms that have an agreement with CML, that is, Saleroom and Lot-tissimo. In what concerns the national customers, their presence is stronger on online-only auctions conducted through CML's own platform. This proved to be a great advantage, bringing to the auction world many people who were not prone to leave the comfort of their homes at night or who are living far away from Lisbon: "The internet is a great advantage ( ... ). We don't spend money sending catalogues by mail, except for our live auctions. Since every week we have two new auction catalogues in our online platform, everyone can see what is going to sale without having to wait for a large printed catalogue. This brought us a large number of customers from small places all around Portugal, especially in our online-only auctions. People that are living $100 \mathrm{~km}$ or $400 \mathrm{~km}$ away from here and that buy from us something every month" (INT05).

Additionally, by conducting almost two online-auction every week, the company also found a solution to the problems of cash flow management: "With the online-only auctions we solved $100 \%$ of our cash flow necessities. Every week we get EUR 50,000 to EUR 60,000 from these auctions. As we

5 This is a provisional percentage, provided by one of CML CEO's on an email dated from 4 January 2020. 
do payments to our vendors 30 days after the sale, we always have a good cash flow. Just like the supermarkets. Even in the summertime, when business is down" (INT01).

In terms of employees, before the move to online-only auctions, CML rose from a minimum of eight full-time employees in 2008 to a maximum of 14 employees in 2013 and 2014 (Figure 7). These numbers grew significantly when online auctions became much more relevant: 18 full-time employees in 2017, and 22 in 2018: "In a certain way, we changed printing costs, nearly EUR 30,000 to EUR 40,000 per catalogue, of which we are making four or five less per year, for costs with salaries, hiring more people and increasing these costs in nearly EUR 300,000 per year" (INT04). Concerning part-time employees, consultants and trainees, CML evolved from a minimum of ten people in 2008 to a maximum of 25 in 2015 and 2018, although in 2011, 2012 and 2014 CML already had a high number of collaborators with these characteristics, counting with 22 people.

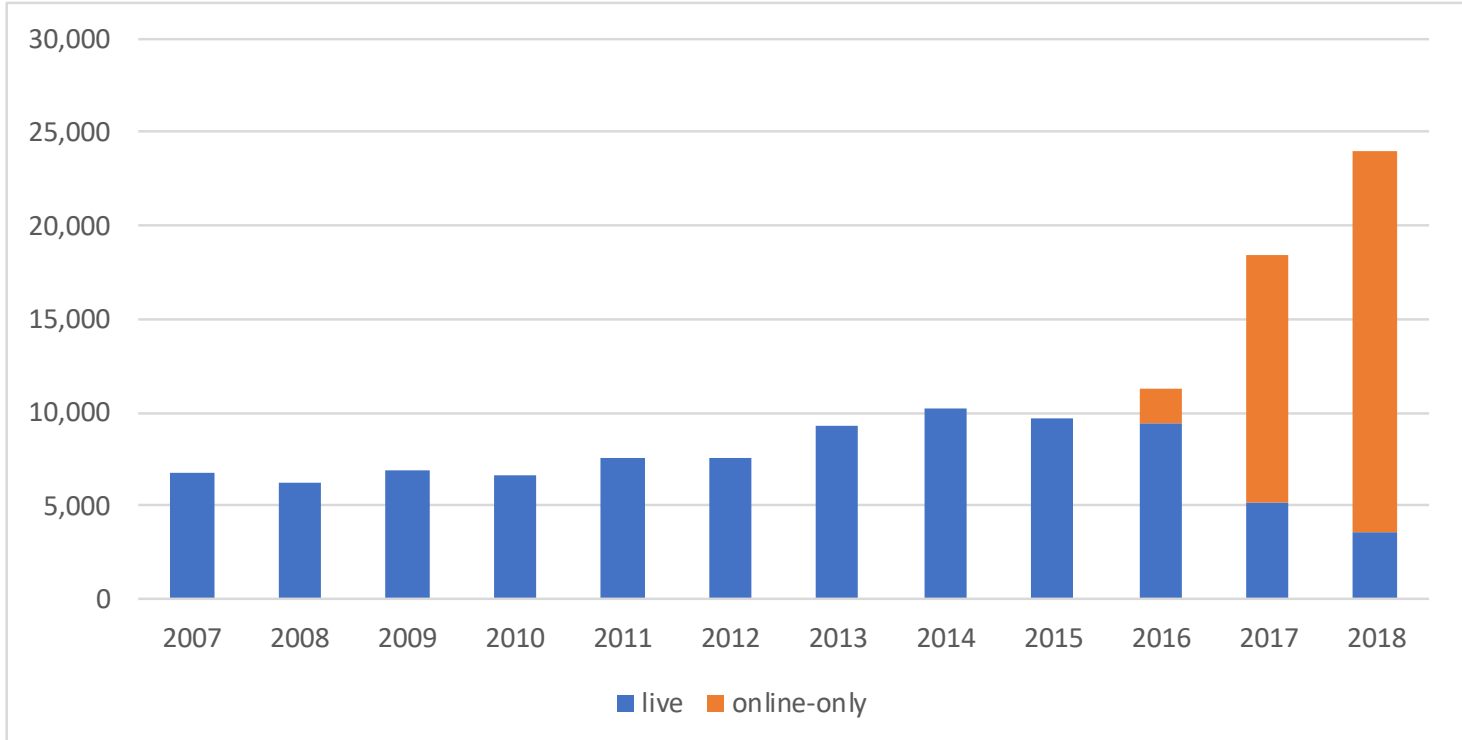

Figure 6. Total number of lots taken to auction (live and online-only) (2007-2018).

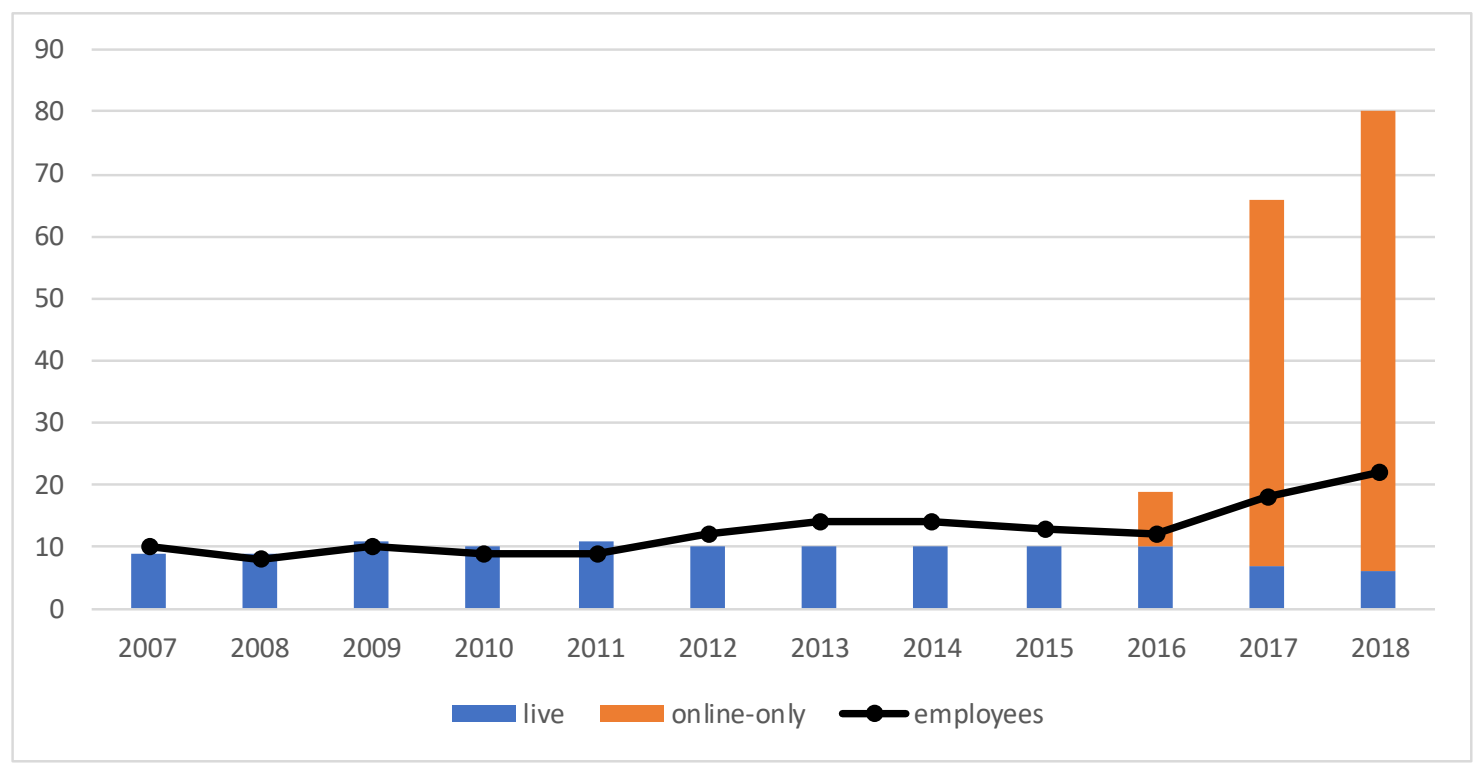

Figure 7. Number of full-time employees and auctions held (live and online-only) (2007-2018).

Considering the average lot price, the quantity of lots taken to auction per year, and the number of auctions conducted yearly, we understand how and why this company needed to change its business 
model. Between 2007 and 2015, the number of lots that CML took to auction varied between a minimum of 6.204 lots, in 2008, and a maximum of 10.236 lots, in 2014. After having introduced exclusively online auctions in the last quarter of 2016, these numbers rose to 11.213, in 2016, 18.418, in 2017, and 24.017, in 2018. Before the introduction of online auctions, the average price varied between a maximum of EUR 1.689 in 2011 and a minimum of EUR 934 in 2014 (Figure 8). After the beginning of online auctions, these values have been diminishing year after year: EUR 898 in 2016, EUR 392 in 2017, and EUR 370 in 2018. However, if we center our attention only on the average price of lots sold online, the tendency is more promising: EUR 67 in 2016, EUR 103 in 2017 and EUR 143 in 2018.

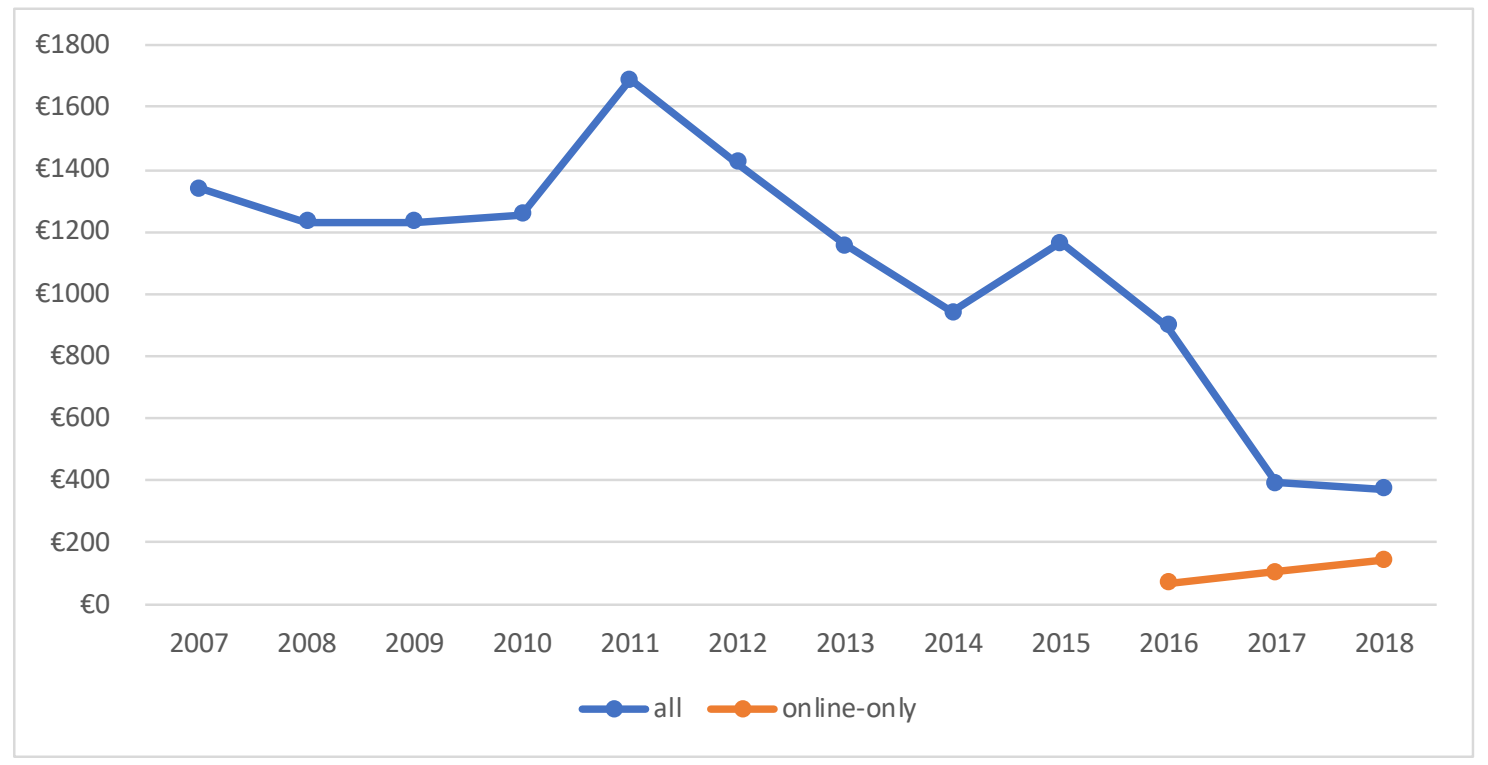

Figure 8. Average price of lots sold (2007-2018).

\section{Conclusions}

Cabral Moncada Leilões (CML) business continues to be holding auctions of works of art and antiques. In this sense, its business model continues to be the same, taking commissions from both sellers and buyers in exchange of a service. However, from a management perspective, CML has changed significantly over the last 12 years in terms of strategy, market positioning, technology and processes.

In 2007, CML made nine auctions on its premises, taking to auction 6.779 lots, selling 4.643 of them, which generated a turnover of EUR 6.2 million reaching an average price of EUR 1.336 per lot. At that time, its main goal was to occupy the top-tier of the Portuguese auction market, competing with the incumbent auction house and with any additional competitor that might arise. The goal was to have a company mainly focused on the top and upper-middle segments of the Portuguese market.

In 2018, CML only made six live auctions on its premises, but organized 74 online-only auctions. It took to auction a total of 24.017 lots, of which 20.384 were online-only auctions, selling, respectively, 17.457 lots online and 2.178 lots in its premises. The turnover reached EUR 6.44 million, and one third was achieved with online-only auctions. Between 2008 and 2018, the number of full-time employees almost tripled, raising from eight to 22. In contrast with other second-tier companies worldwide, who get nearly three-quarters of their online sales through third-party electronic platforms, such as Invaluable, LiveAuctioneers and Artsy (McAndrew 2019, p. 274), CML was able to develop its own online platform successfully, avoiding a reduction of its margins due to the fees charged by these platforms. On average, these auction houses get $19 \%$ of their turnover through online sales. Therefore, CML is clearly above the average, since in 2018 its online sales already represented $33.5 \%$ of its total turnover, a percentage that should grow to $40 \%$ in 2019. 
CML continues to be one of the two top auction houses in the Portuguese market, but its strategy has changed. It reserves the most expensive and best works of art for live auctions, making only half of the live auctions it did in the past. Every week, CML holds an online auction with antiques and works of art, and once a month makes an auction exclusively for silver and jewels and another one for furniture and large pieces. CML is now getting a higher and higher percentage of its revenue from an avalanche of lots sold on its own online auction platform, which provide a large and continuous revenue to the company due to the scale and continuity of online sales. However, CML also benefits from higher commissions (low-price lots pay higher commissions than the most expensive ones, due to a system of progressive price ranges), and from lower production costs (photography, cataloguing, exhibition, storage, transportation, etc.). In the next few years, the challenge for CML will be to maintain the recognition of the market as a top-tier auction house, while at the same time securing most of its revenue from mid-tier goods.

Author Contributions: The interviews and the analysis of the collected materials were conducted by the two authors together. The conceptualization of this paper and its methodology, the validation of the information, as well as the writing, reviewing and editing of the draft were developed by the two authors in close collaboration and dialogue. Both have read and agreed to the published version of the manuscript.

Funding: This research received no external funding.

Acknowledgments: The authors acknowledge the support given by the managers and collaborators of Cabral Moncada Leilões to conduct this study.

Conflicts of Interest: The authors declare no conflict of interest.

\section{References}

Adam, Georgina. 2014. Big Bucks: The Explosion of the Art Market in the Twenty-First Century. London: Lund Humphries.

Adam, Georgina. 2017. Dark Side of the Boom. The Excesses of the Art Market in the 21st Century. London: Lund Humphries.

Afonso, Luís U. 2012. Caraterísticas e tendências do mercado leiloeiro português nos últimos anos. In Os Leilões e o Mercado da Arte em Portugal. Edited by Alexandra Fernandes and Luís U. Afonso. Lisbon: Scribe, pp. 7-31.

Afonso, Luís U., and Alexandra Fernandes. 2019. Mercados da Arte. Lisboa: Sílabo.

Boloten, Jeffrey. 2016. The contemporary photography market. In Art Business Today. 20 Key Topics. Edited by Jos Hackforth-Jones and Iain Robertson. London: Lund Humphries, pp. 69-73.

De Tomasi, Filippo. 2013. As galerias de arte contemporânea portuguesas: O cenário depois da crise de 2008. Cadernos de História da Arte 1: 164-71.

Ehrmann, Thierry. 2016. The Art Market in 2015. St-Romain-au-Mont-d'Or: artprice.com/Amma, Available online: https://imgpublic.artprice.com/pdf/rama2016_en.pdf (accessed on 20 January 2020).

Fernandes, Alexandra, and Luís U. Afonso, eds. 2012. Leilões e o Mercado da Arte em Portugal. Lisbon: Scribe.

Flynn, Tom. 2016. The A-Z of the International Art Market. The Essential Guide to Customs, Conventions, and Practice. New York: Bloomsbury.

Hackforth-Jones, Jos, and Iain Robertson, eds. 2016. Art Business Today. 20 Key Topics. London: Lund Humphries.

Hiscox. 2019. Hiscox Online Art Trade Report. Available online: https://www.hiscox.co.uk/online-art-trade-report (accessed on 19 December 2019).

Horowitz, Noah. 2011. Art of the Deal: Contemporary Art in a Global Financial Market. Princeton: Princeton University Press.

Johansson, Tobias, and Johan Kask. 2017. Configurations of business strategy and marketing channels for e-commerce and traditional retail formats: A qualitative comparison analysis (QCA) in sporting goods retailing. Journal of Retailing and Consumer Services 34: 326-33. [CrossRef]

Magalhães, João. 2008. Portugal. In The International Art Markets. The Essential Guide for Collectors and Investor. Edited by James Goodwin. London: Kogan Page, pp. 253-63.

McAndrew, Clare, ed. 2010. Fine Art and High Finance. New York: Bloomberg Press. 
McAndrew, Clare. 2019. The Art Market. 2019. The Art Basel and UBS Global Art Market Report|2019. Basel: Art Basel and UBS, Available online: www.artbasel.com/about/initiatives/the-art-market (accessed on 19 December 2019).

McNulty, Tom. 2014. Art Market Research: A Guide to Methods and Sources, 2nd ed. Jefferson: McFarland and Company.

Milano, Ronit. 2019. Moralizing the Art Market: A Socioeconomic Perspective on Art Auctions on the Floor and Online. Journal for Art Market Studies 3: 1-18.

Morse, Janice. 2015. Data were saturated. Qualitative Health Research 25: 587-88. [CrossRef] [PubMed]

Moulin, Raymonde. 2003. Le Marché de L'art: Mondialisation et Nouvelles Technologies. Paris: Flammarion.

Moureau, Nathalie, and Dominique Sagot-Duvauroux. 2012. Four business models in contemporary art. International Journal of Arts Management 14: 44-56.

Nabais, Débora. 2015. Economic and Financial Analysis of the Portuguese Art Market. Master's. dissertation, ISCTE-IUL, Lisbon, Portugal.

Patton, Michael. 2002. Qualitative Research E Evaluation Methods. Thousand Oaks: Sage.

Portugal. 2019. Portugal Country Review; Houston: CountryWatch Publications. Available online: http: //www.countrywatch.com/content/pdfs/reviews/B4363663.01c.pdf (accessed on 23 December 2019).

Pownall, Rachel. 2017. Tefaf. Art Market Report 2017. Helvoirt: Tefaf, Available online: https:/www.tefaf.com/tefaf/media/website/fair\%20images/tefaf\%20maastricht/2017/art\%20symposium/ tefaf-art-market-report-online-focus.pdf (accessed on 22 December 2019).

Ramires, Maria. 2018. Galerias de Arte em Lisboa. Passado e Presente. Master's. dissertation, ISCTE-IUL, Lisbon, Portugal.

Robertson, Iain. 2016. Understanding Art Markets. Inside the World of Art and Business. London: Routledge.

Saleroom. 2019. About us. Saleroom. Available online: https://www.the-saleroom.com/en-gb/about-us (accessed on 7 November 2019).

Samdanis, Marios. 2016. The impact of new technology on art. In Art Business Today. 20 Key Topics. Edited by Jos Hackforth-Jones and Iain Robertson. London: Lund Humphries, pp. 164-72.

Sheffield, Hazel. 2017. Artfinder: The online art market using AI to match paintings to buyers. The Independent. August 24. Available online: https://www.independent.co.uk/news/business/indyventure/artfinder-onlineart-marketplace-ai-paintings-buyers-gallery-a7897876.html (accessed on 21 December 2019).

Sidorova, Elena. 2019. The Cyber Turn of the Contemporary Art Market. Arts 8: 84. [CrossRef]

Simões, Pedro. 2015. O Mercado da Arte Moderna e Contemporânea em Portugal (2005-2013). Ph.D. disssertation, Universidade de Lisboa, Lisbon, Portugal.

Teixeira, João. 2012. O Mercado leiloeiro em Portugal (2005-2012). A crise financeira: Efeitos e consequências. In Os Leilões e o Mercado da Arte em Portugal. Edited by Alexandra Fernandes and Luís U. Afonso. Lisbon: Scribe, pp. 39-49.

Velthuis, Olav. 2005. Talking Prices. Symbolic Meanings of Prices on the Market for Contemporary Art. Princeton: Princeton University Press.

Victor, Vijay, Jose Thoppan, Robert Nathan, and Maria Farkas. 2018. Factors influencing consumer behavior and prospective purchase decisions in a dynamic pricing environment: An exploratory factor analysis approach. Social Sciences 7: 153. [CrossRef]

Vrchota, Jaroslav, Tomas Volek, and Martina Novotná. 2019. Factors Introducing Industry 4.0 to SMES. Social Sciences 8: 130. [CrossRef]

Wu, Jen-Her, and Tzyh-Lih Hisa. 2004. Analysis of E-commerce innovation and impact: A hypercube model. Electronic Commerce Research and Applications 3: 389-404. [CrossRef]

Zarobell, John. 2017. Art and the Global Economy. Oakland: University of California Press.

Zorloni, Alessia. 2013. The Economics of Contemporary Art. Heidelberg: Springer.

(C) 2020 by the authors. Licensee MDPI, Basel, Switzerland. This article is an open access article distributed under the terms and conditions of the Creative Commons Attribution (CC BY) license (http://creativecommons.org/licenses/by/4.0/). 